\title{
Jalan Tengah: Kritik Paradigma Pendidikan di Barat (Sebuah Kajian Filosofis Historis)
}

\author{
Rz. Ricky Satria Wiranata \\ Prodi Manajemen Dakwah, Sekolah Tinggi Agama Islam Terpadu, Yogyakarta
}

\begin{tabular}{|c|c|}
\hline Article Info & ABSTRACT \\
\hline Article history: & The scientific history of the Western nations began from the era of ancient \\
\hline Received Apr 17, 2020 & Greece until the modern era has given birth to paradigms that affect Western \\
\hline Accepted Aug 3, 2020 & $\begin{array}{l}\text { thought systems such as the paradigm of rationalism, empiricism, criticism, } \\
\text { positivism which also had a massive impact on the Eastern world. To prove }\end{array}$ \\
\hline & the truth, the West uses the paradigm of wonder and doubt to confirm the \\
\hline & $\begin{array}{l}\text { the education system in the West is not necessarily without disabilities. There } \\
\text { are at least three things that are the core values of Western science that are }\end{array}$ \\
\hline Western Education & criticized by researchers, namely secularism, dichotomy and \\
\hline Islamic Education & anthropocentrism. Finally, the author presents a middle ground for the \\
\hline Philosophy & $\begin{array}{l}\text { Islamic Education Paradigm, namely returning to revelation as a tool and } \\
\text { source of knowledge, revelation will bring religiosity and lead to } \\
\text { ecocentrism. This research is important because it seeks to find a middle } \\
\text { ground over the incomplete philosophical theoretical footing between } \\
\text { Western Education and Islamic Education. This research is a qualitative } \\
\text { research (heritage study), the approach used is historical philosophical. }\end{array}$ \\
\hline
\end{tabular}

This is an open access article under the CC BY-SA license.

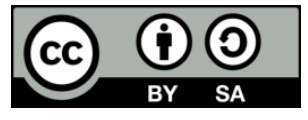

\section{Corresponding Author:}

Rz. Ricky Satria Wiranata

Prodi Manajemen Dakwah, Sekolah Tinggi Agama Islam Terpadu, Yogyakarta

E-mail: rickysatriawiranata@gmail.com

\section{PENDAHULUAN}

Sejarah panjang perkembangan ilmu pengetahuan dimulai dari periode Yunani Kuno hingga periode kontemporer telah berhasil membuktikan peranan filsafat sebagai induk segala ilmu pengetahuan. Eksistensi filsafat dapat dilihat dari munculnya berbagai macam disiplin ilmu yang semakin hari semakin matang dan spesifik, salah satunya adalah ilmu Pendidikan. Filsafat mengambil posisi sebagai mother of science hal ini menjadikan filsafat menjadi kajian khusus yang tidak akan pernah usai karena epistemologi ilmu yang berangkat dari keheranan. Keheranan yang diproses dengan penalaran yang benar akan menghasilkan sumbangsih ilmu pengetahuan bagi peradaban manusia. Filsafat menemukan sebuah metode belajar dari keheranan dan memunculkan keinginan untuk menyusun sesuatu hal secara empiris logis serta dapat diukur sesuai aturan logika yang benar. Sejarah mencatat, orang Yunani merupakan bangsa pertama yang mampu menyusun secara sistematis sekaligus perintis terbentuknya ilmu pengetahuan. Dari sinilah awal kemenangan ilmu pengetahuan atas mitos-mitos, dan kepercayaan tradisional yang berlaku di masyarakat Barat (George, J. Mouly, 2014: 276).

Jika kita cermat, ada yang menarik dalam tradisi keilmuan di Barat, yaitu paradigma pendidikan yang selalu diarahkan untuk pembuktian kebenaran yang tidak pernah usai dan selalu diragukan dengan keheranan-keheranannya. Sehingga muncullah berbagai macam teori dan paradigma yang mempengaruhi tata kelola berfikir dan sistem pendidikan di Barat. Bagi filsafat, kedudukan teori dan paradigma adalah view of life atau pandangan hidup dalam memutuskan keputusan-keputusan yang bijak dalam kehidupan. Teori dan paradigma juga menjadi peta konsep dan kompas keilmuan yang berpijak atas asumsi-asumsi 
dasar yang menjadi pengarah manusia untuk memperoleh kebenaran. Hal ini membuat kita sadar bahwa bangsa Barat telah mampu menghadirkan SDM yang unggul tentu melalui sistem pendidikan yang berorientasi kepada kepastian kebenaran dan eksperimentasi keraguan.

Sebuah teori mengatakan, semakin modern suatu peradaban manusia makin melemah komitmen manusia terhadap Agama. Peradaban modern muncul akan menghancurkan esensi kehidupan karena modernitas akan menghalau sendi-sendi agama menuju sekulerisasi, puncaknya adalah munculnya Tuhan-Tuhan baru yang menjadi sesembahan manusia (Syamsudin Arif, 2008: 84). Yang mengkhawatirkan, praktik sekulerisasi justru telah merambah dalam dunia Islam bahkan telah menjadi ideologi bagi segelintir orang. Sekulerisasi dianggap menjadi persyaratan transformasi tradisional menuju modern. Padahal jika ditelaah lebih lanjut, bangsa Barat mungkin tidak akan menikmati kemajuan ilmu pengetahuan saat ini jika tidak ada proses transmisi ilmu pengetahuan melalui penerjemahan karyakarya Yunani kedalam Bahasa Arab (Sri Suyanta, 2011: 26). Tidak hanya diterjemahkan, namun Muslim ikut mengomentari, memodifikasi dan mengasimilasi karya-karya fenomal bangsa Yunani (Hamid Fahmi Zarkasyi, 2013: 183). Hematnya, Islam telah membuka jalan bagi peradaban Barat melalui berbagai kreasi, uji coba, penemuan dan teori-teori dasar yang telah dirumus, namun tetap mempertahankan dan mengembangkan kehidupan beragama (Ahmad Asmuni, 2017: 181).

Berdasarkan kajian diatas, modernitas Barat ternyata menyiratkan kegagalan dan kebobrokan dalam sistem pendidikan di berbagai aspek seperti sekulerisasi, dikotomi hingga antroposentrisme. Di sisi lain, Islam memberi cahaya dan pengaruh besar terhadap perkembangan ilmu pengetahuan dan teknologi di Barat yang dianggap tradional dan penonton dalam peradaban modern. Hal ini semakin menarik untuk dianalisis bagaimana jalan tengah dan solusi bagi paradigma pendidikan Islam, sehingga Islam dapat memposisikan diri sebagai kaum modern tanpa meninggalkan identitas berketuhanan. Artikel ini dimulai dari sejarah keilmuan Barat, kemudian Paradigma Pendidikan Barat hingga kritik atas praktik epistemologi pendidikan di Barat dengan membenturkan paradigma Islamic Core Values. Di akhir tulisan ini, peneliti menyajikan jalan tengah dan solusi konkret bagi Paradigma Pendidikan Islam. Peneliti berharap, artikel ini dapat memberikan sumbangsih keilmuan dan ikut meningkatkan khazanah keilmuan dalam Filsafat Pendidikan Islam.

\section{METODE}

Artikel ini merupakan hasil penelitian studi pustaka yang bersifat kualitatif. Studi pustaka merupakan penelitian yang dilakukan dengan cara mengumpulkan data, informasi dan berbagai macam sumber lainnya yang terdapat dalam kepustakaan (Joko Subagyo, 1991: 109). Penyusunan karya ilmiah berbasis study pustaka didasarkan pada hasil studi pustaka seperti buku, jurnal ilmiah, berita dan lain sebagainya yang berkaitan Paradigma Pendidikan Barat dan Pendidikan Islam.

Adapun pendekatan yang digunakan dalam penelitian ini adalah pendekatan filosofis historis. Pendekatan filosofis adalah mencari struktur ide-ide dasar dari sebuah pemikiran tokoh (Anton Bekker, 1984: 141). Sedangkan pendekatan historis adalah membuat rekonstruksi masa lampau secara sistematis dan objektif, dengan cara mengumpulkan, mengevaluasi, memverifikasi, serta mensintesiskan bukti-bukti untuk menegakkan fakta dan memperoleh kesimpulan yang akurat (Sumadi Suryabrata, 2005: 73).

\section{HASIL DAN PEMBAHASAN}

\section{Sejarah Keilmuan Barat}

Sejarah hakikatnya tidak bergerak atau berproses dalam situasi yang kosong. Karena sejarah adalah bagian dari kehidupan yang tercipta dari sebuah rentetan yang berlangsung dari masa lampau hingga saat ini (Mohammad Maiwan, 2013: 160). Ahli sejarah silang pendapat dalam mendefinisikan term sejarah. Namun dapat kita simpulkan bahwa pada intinya sejarah adalah kesinambungan atau rentetan suatu peristiwa atau kejadian antara masa lampau, masa sekarang dan masa depan. Hal ini dapat kita ketahui dari aspek kronologis dan aspek geografis karena di setiap periode pasti memiliki ciri khas yang berbedabeda. Namun dalam konteks periodesasi dalam perkembangan ilmu, maka memiliki perbedaan di berbagai literatur yang ada. (Abdul Karim, 2014: 275). Perbedaan dalam berbagai aspek tersebut menjadikan sejarah selalu menarik untuk dikaji karena selalu memunculkan fakta-fakta baru yang menarik tentang dinamika masa lampau.

Menurut HF. Zarkasyi peradaban modern di awali dari Era Yunani kemudian Romawi kemudian Abad Pertengahan (Hamid Fahmi Zarkasyi, 2013: 176). Sedangkan sejarah keilmuan di Barat dibagi menjadi empat periode yaitu pada periode Yunani kuno, periode the dark ages, periode renaisance, periode modern, dan periode kontemporer (Abdul Karim, 2014: 275). Sejarah keilmuan barat harus dipahami secara komprehensif, sehingga kita membuka fakta dengan elaborasi dan klasifikasi di setiap 
periode perkembangan ilmu pengetahuan di Barat. Empat periode tersebut merupakan sejarah panjang bangsa Barat yang hingga saat ini telah menguasai berbagai ilmu pengetahuan dan memperoleh dominasi keilmuan saat ini. Lebih jelas periode tersebut akan dituangkan dibawah ini sebagai berikut:

\section{Periode Yunani Kuno}

Yunani kuno adalah tempat bersejarah dimana sebuah bangsa mempunyai peradaban yang tinggi. Bangsa Yunani Kuno ter citra sebagai philosophy central dan menjadi pusat berkembangnya ilmu pengetahuan. Padahal, jika membaca literatur lain, maka filsafat dalam pengertian yang sederhana sudah sangat berkembang jauh para filosuf klasik Yunani menekuni dan mengembangkan filsafat. Di tangan pada filosuf Yunani Kuno, ilmu pengetahuan berkembang dengan pesat dan menjadi sesuatu yang sangat bernilai di mata masyarakat hingga abad kontemporer. Filsafat di ibaratkan seperti pintu gerbang utama untuk melahirkan ilmu-ilmu cabang yang dikaji semakin mandiri dan terpisah dari filsafat. Menurut Bertrand, dari sekian banyak sejarah, tidak ada yang lebih mengherankan melainkan begitu mendesaknya kelahiran peradaban Yunani di tengah peradaban lain yang belum berkembang dengan mapan. Sekalipun masih banyak peradaban dan berumur ribuan tahun seperti di Mesir dan Mesopotamia. Namun unsurunsur lain masih belum komprehensif hingga kemudian bangsa Yunani menyempurnakannya (Bertrand Russell dalam Abdul Karim, 2014: 277).

Seiring dengan perubahan zaman, ilmu filsafat berubah menjadi epistemologi bangsa Yunani untuk menjawab teka-teki alam melalui ilmu pengetahuan, atas dasar tersebut generasi penerus selanjutnya berkembang dengan cepat. Bangsa Yunani ibarat membuka pintu-pintu berbagai macam disiplin ilmu dan berpengaruh besar hingga sekarang. Oleh sebab itu, masa perkembangan filsafat Yunani adalah titik awal untuk memasuki peradaban yang lebih maju dari umat manusia. Zaman ini diperkirakan berlangsung mulai dari abad ke-6 SM hingga sekitar abad ke-6 M. Ciri-ciri zaman ini dapat dilihat dari sikapnya yang senang menyelidiki suatu perkara secara mendalam dan kritis, dan menolak seluruh pengalaman yang didasarkan sikap menerima begitu saja. Sehingga wajar jika pada zaman ini filsafat tumbuh dengan subur. Dengan berkembangnya filsafat, maka bangsa Yunani dapat mengukuhkan dirinya pada puncak kejayaan atau yang disebut the golden age era (Amsal Bakhtiar dalam Abdul Karim, 2014: 277).

Era ini banyak bermunculan para ilmuwan yang terkemuka. Di antaranya adalah Thales tahun 624545 SM, Pythagoras tahun 580 SM-500 SM, Socrates tahun 469 SM-399 SM, Plato tahun 427 SM-347 SM, Aristoteles tahun 384 SM- 322 SM. Secara umum, tokoh-tokoh tersebut memberikan sumbangsih pemikiran dasar kritis atas fenomena kealaman yang selalu di benturkan dengan rasionalitas. Fenomena alam dan mitologi Dewa-Dewa menjadi pijakan awal untuk memulai berfikir kritis dan terus berlanjut pada periode selanjutnya hingga sekarang.

\section{Periode The Dark Ages}

Barat menyebut periode ini sebagai abad pertengahan atau sekitar abad ke-9 sampai abad ke-14, sebutan lain yang disematkan pada periode adalah The Dark Ages (abad kegelapan). Istilah hanya bagi peradaban dunia Barat, seperti di wilayah jajahan Romawi Kristen yang mengalami kegelapan dan kebodohan. Cerita menarik datang dari Kilyam Dabur wali kota Thabariyah mengisahkan bahwa seorang jawara penunggang kuda mengalami sakit keras sehingga dibawalah kepada seorang Uskup Agung untuk mendapatkan pengobatan. Di saat Uskup melihat pasien, kemudian Uskup meminta lilin, kemudian lilin kami berikan kepadanya, setelah itu dia melemaskan nya dan membentuknya seperti ruas jari, kemudian masing-masing lilin tersebut diletakkan di hidungnya. Tidak lama kemudian itu sang jawara akhirnya meninggal dunia. Kami berkata kepadanya bahwa dia telah meninggal. Dia bilang ya, dia tadi tersiksa maka saya sumbat lubang hidungnya sampai mati dan tenang dalam peristirahatannya (Amsal Bakhtiar dalam Abdul Karim, 2014: 2).

Cerita tersebut mencerminkan bagaimana gelapnya ilmu pengetahuan khususnya ilmu kedokteran yang terbelakang di dunia Barat. Cerita tersebut sebagai karikatur sejarah kelam bangsa Barat yang sangat kelam pada periode the dark ages. Penyebab utama matinya ilmu pengetahuan di Barat karena matinya fungsi akal yang kritis atas fenomena alam, sosial dan manusia. Abad ini dicirikan munculnya para nabinabi yang menyampaikan wahyu Tuhan sebagai petunjuk manusia. Namun, munculnya para nabi tampaknya tidak dapat dijadikan sebagai sumber kekuatan baru bangsa Barat untuk melanjutkan adidaya Yunani Kuno atas perkembangan ilmu dan teknologi berseragam dogma agama. Justru, kedatangan nabi membelenggu bangsa Barat karena sentimen agama yang membutakan akal. Dogma agama dan belenggu gereja tampaknya menjadi penyebab mendasar sehingga dunia Barat masuk pada periode yang disebut the dark ages.

Hal ini sangat berbeda jauh dengan peradaban Islam timur yang jauh lebih maju dan jauh meninggalkan peradaban Barat yang semakin terbelakang. Periode ini diawali penerjemahan buku-buku Yunani dan kembali hidupnya pungsi filsafat dalam peradaban Islam. Menariknya, kemajuan ini justru 
bersinggungan erat dengan wahyu Tuhan dan telah menjadi satu kesatuan yang tidak dapat dipisahkan, dibuktikan dengan munculnya tokoh-tokoh filsafat sekaligus para ulama seperti al-Ghozali, al-Farabi, alKindi, dll. Bagi Islam abad ini disebut Ashr al-Izdihar (zaman kejayaan) dan Al-Ashr Adz-Dzahabi (zaman keemasan). Disaat kondisi barat dalam keadalan gelap dari berbagai ilmu, sebaliknya peradam Islam timur justru terang benderang, bahkan peradaban Islam Timur mampu menerangi kegelapan dalam peradaban Barat (Hasyim Asy'ari, 2018: 2). Sebut saja, seorang tokoh bernama al-Kindi, beliau adalah seorang filosuf Islam yang berjasa dalam membuat fondasi filsafat Islam dan berkembang sehingga Islam Timur mendapatkan peradaban maju dibandingkan bangsa lain, kemudian pondasi tersebut dilanjutkan dan dikembangkan oleh al-Farabi. Al-Farabi menginginkan bangsa Arab mengenal filsafat Yunani dan tidak apatis terhadapnya sebagaimana kaum kristen ortodoks yang menolak pengetahuan asing (Felix Klein-Franke dalam Abdul Karim, 2014: 284).

Menurut Harun Nasution, keilmuan yang berkembang pada periode ini dipengaruhi oleh persepsi tentang bagaimana tingginya kedudukan akal seperti yang terdapat dalam al-Qur`an dan al-Hadis. Persepsi ini bertemu dengan persepsi yang sama dari Yunani melalui filsafat dan sains Yunani yang berada di kota-kota pusat peradaban Yunani di Dunia Islam Zaman Klasik, seperti Alexandria (Mesir), Jundisyapur (Irak), Antakia (Syiria), dan Bactra (Persia). Selain disiplin-disiplin ilmu di atas, sebagian umat Islam juga menekuni logika dan filsafat. Sebut saja al-kindi, alfarabi (950 M), Ibn Sina atau Avicenna (1037 M), al-ghozali (1111 M), Ibn Majah atau Avempace (1138 M), Ibn Tufail atau Abubacer (1185 M), dan Ibn Rushd atau Averroes (1198 M).

\section{Masa Renaissance dan Modern}

Zaman Renaissance (antara abad 14 sampai 16 masehi) adalah satu abad keemasan (Golden Age) dalam sejarah peradaban barat. Era ini adalah fase transisi yang menghubungkan zaman kegelapan (Dark Ages) dengan zaman pencerahan (Enlightenment Age). Dengan lahirnya zaman kebangkitan maka peradaban Barat dapat bersinar dan mulai mendominasi atas peradaban di dunia. Tanpa Renaissance, bangsa Eropa mungkin tidak akan memperoleh abad-abad modern dengan cepat sebagaimana saat ini (Ahmad Suhelmi, 2007: 106).

Renaissance adalah periode perkembangan peradaban yang terletak di ujung atau sesudah abad kegelapan sampai muncul abad modern. Renaissance merupakan era sejarah yang penuh dengan kemajuan dan perubahan yang mengandung arti bagi perkembangan ilmu. Ciri utama renaissance yaitu humanisme, individualisme, sekularisme, empirisme, dan rasionalisme. Sains berkembang karena semangat dan hasil empirisme, sementara Kristen semakin ditinggalkan karena semangat humanism (Abdul Karim, 2014: 285).

Pengaruh ilmu Islam terhadap Eropa yang telah berlangsung sejak abad ke-12 M ternyata menimbulkan gerakan renaissance pusaka Yunani di Eropa pada abad ke-14 M. Berkembangnya pemikiran Yunani di Eropa pada saat itu melalui penerjemahan naskah berbahasa Arab kedalam bahasa latin kemudian dipelajari kembali ke dalam bahasa latin. Sekalipun Islam pada akhirnya harus terusir dari Spanyol dengan cara keji, tetapi Islam telah membidangi gerakan-gerakan penting dalam peradaban Eropa. Gerakan-gerakan tersebut adalah era kebangkitan kembali kebudayaan Yunani klasik sekitar abad ke-14 M, rasionalisme sekitar abad ke-17 M, dan pencerahan sekitar abad ke-18 M (K. Bertens, 1986: 32).

Periode renaissance ditandai dengan cepatnya perkembangan ilmu dan teknologi di dunia Barat. Perkembangan ilmu pengetahuan yang sebelumnya menjadi kejayaan Islam dan berlangsung cukup lama namun kembali diambil alih dan bangsa Barat masuk pada periode kehancuran kejayaan Islam atau periode kegelapan bagi bangsa Timur sebagaimana bangsa Barat sebelumnya. Kehancuran kejayaan Islam disebabkan karena carut marutnya sistem tata kelola pemerintah yang dipimpin Islam karena politik internal yang tidak berkesudahan, perebutan kekuasaan, pemakzulan terhadap khalifah dan banyak faktor lainnya, mejadi penyebab dasar hancurnya kejayaan Islam. Hal ini dimanfaatkan bangsa Barat melalui peperangan panjang dan akhirnya memperoleh kemenangan besar bagi bangsa Barat atas Timur. Kehancuran kejayaan Islam menjadi alarm bahwa bangsa Barat telah memasuki periode yang disebut renaissance atau kebangkitan kembali bangsa Barat.

\section{Periode Kontemporer}

Era ini bermula sekitar abad 20 masehi dan masih berlangsung hingga era saat ini. Peradaban maju bangsa Barat ditandai dengan bermunculan nya teknologi-teknologi modern, selain itu spesialisasi ilmuilmu yang semakin mendalam dan berpisah secara independent. Pada era ini bidang fisika memperoleh kedudukan paling tinggi dan sering dibicarakan oleh para pemikir dalam setiap mimbar-mimbar akademik. Sehingga wajar jika sebagian besar ilmu dan teknologi pada abad 21 adalah hasil penemuan fenomenal abad 20. Salah satu Fisikawan yang paling terkenal pada abad ke-20 adalah Albert Einstein. 
Sebagai seorang ilmuwan fisika, Einstein lahir pada tanggal 14 Maret, Einstein menemukan teori relativitas dan banyak menyumbang bagi pengembangan mekanika kuantum, mekanika statistik, dan kosmologi (Surajiyo, 2007: 89). Sebagai fisikawan, Albert Einstein sukses menjadi ilmuwan dan menambahkan khazanah keilmuan Barat yang semakin maju pada periode ini.

Teknologi komunikasi dan informasi berkembang pesat pada zaman ini. Pada eranya banyak penemuan yang merubah wajah dunia seperti: Listrik, Elektronika, Mesin Produksi, Mesin Pertanian, Televisi, Radio, Nuklir, Transportasi, Komputer, Internet, Pesawat Terbang, Telepon, Perminyakan, Teknologi Luar Angkasa, AC dan Kulkas, Rekayasa Material, Teknologi Kesehatan, Fiber Optic dan lain sebagainya. Keberhasilan dan penemuan-penemuan tersebut menghidupkan asa manusia untuk mengembangkan system dan efisiensi energi yang jauh lebih tinggi daripada sebelumnya. Salah satu contohnya adalah penemuan memori, jika power/listrik dalam keadaan mati maka tidak perlu jeda bagi komputer boot up, sehingga dalam kondisi tanpa listrik kita dapat mempertahankan informasi yang disimpan dalam memori (Jadiwijaya dalam Abdul Karim, 2014: 287).

Penemuan-penemuan ilmiah tersebut menjadi bukti pesatnya perkembangan ilmu pengetahuan dan teknologi bangsa Barat. Bangsa Barat telah menduduki sebagai bangsa maju dalam peradaban keilmuan dan teknologi. Sangat kontras jika dibandingkan bangsa barat pada periode kegelapan dahulu, dimana kebodohan merongrong bangsa Barat sehingga cukup puas dengan pengagum ilmu pengetahuan Timur, persis seperti bangsa Timur (Islam) saat ini yang bergantian menempati posisi tersebut. Fakta sejarah ini menunjukkan kehidupan di dunia ini seperti roda mobil, kadang diatas kadang dibawah, kadang maju kadang mundur. Yang jelas tidak ada pilihan untuk jalan ditempat jika bangsa Timur (Islam) ingin kembali duduk pada kursi yang setara dengan bangsa-bangsa Barat yang jauh lebih maju dalam bidang ilmu dan teknologi.

\section{Kritik Paradigma Pendidikan Barat}

Akal dan pancaindra sebagai sumber utama dalam pendidikan. Ciri khas utama dari pendidikan Barat adalah sumber ilmunya yang hanya terbatas pada akal dan panca-indra. Pokok persoalan pendidikan Barat terletak pada sikap menyingkirkan agama, Tuhan atau hal-hal berbau metafisika (Ahmad Khoirul Fata, dkk., 2016: 2019). Paradigma pendidikan seperti ini bisa kita katakan sebagai pendidikan sekuler, dimana wahyu sebagai keabsahan agama tidak mendapatkan peranan sebagai sumber ilmu pengetahuan. Namun, cara ini mampu mengangkat dugaan dan keraguan manusia sebagai sebuah sarana epistemologi dalam pendidikan yang tepat untuk mencapai kebenaran melalui filsafat ilmu Barat (Mahbub Setiawan, 2013: 13). Sekularisasi lahir sebagai dampak atas proses modernisasi yang terjadi pada masa pencerahan secara cepat. Ini terjadi pada peradaban dunia Barat ketika logika agama digeser oleh nalar akal. Sedangkan sekularisme merupakan pemusatan nalar pada dunia lebih banyak dari pada dunia spiritual. Dalam masyarakat sekular, mereka hanya memikirkan bagaimana menggapai kehidupan dunia dan benda-benda materi (Mahbub Setiawan, 2013: 13). Sekulerisasi dalam pendidikan Barat akan menciptakan manusiamanusia pintar namun menyangsikan aspek nilai-nilai ketuhanan. Hal ini tentu menunjukkan kegagalan Barat yang maju dalam ilmu pengetahuan dan teknologi namun justru meninggalkan Tuhan sebagai sumber kebenaran hakiki. Pendidikan Barat memperjelas posisinya sebagai budak dunia dan memilih ragu bahkan mengejawantahkan aspek metafisik. Padahal banyak hal metafisik yang harus dipahami melalui pendekatan religiositas di dunia ini.

Jika kita melihat sejarah, sekulerisasi muncul dilatar belakangi ketidak cocokkan antara dogmadogma gereja terhadap kaum rasionalitas dan pengetahuan sehingga memunculkan perang pemikiran di antara kedua kubu (Jamaludin, 2013: 314). Kecenderungan sekuleristik nampak jelas dibalik zaman renaisans yang menganggap dirinya mendapatkan tugas untuk meneliti secara kritis sesuai dengan kaidah akal termasuk agama (Ridha Ahida, 2018: 4). Sebagai konsekuensinya, pendidikan Barat akhirnya memperjelas praktik dikotomisasi pengetahuan. Hal ini muncul beriringan dengan masa renaissance di Barat. Sebelumnya, kondisi sosio-religius maupun sosio intelektual di Barat dikendalikan gereja. Ajaranajaran Kristen dilembagakan dan menjadi penentu kebenaran ilmiah. Semua temuan ilmiah bisa dianggap sah dan benar bila sesuai dengan doktrin-doktrin gereja. Sebaliknya, jika terdapat temuan ilmiah yang bertentangan dengan paradigma gereja makan temuan tersebut harus dibatalkan. Atas dasar tersebut para ilmuwan mengadakan koalisi dengan raja untuk menumbangkan kekuasan gereja karena dianggap mengebiri aktivitas ilmiah dan memperlambat proses pengembangan ilmu. Pada akhirnya, usaha tersebut berhasil membunuh otoritarianisme gereja kemudian muncullah apa yang disebut dengan masa renaissance. Sehingga wajar, jika Masa renaissance ini akan melahirkan sekulerisasi dan sekulerisasi melahirkan apa yang disebut dikotomisasi pengetahuan (Mujamil Qomar dalam Mahbub Setiawan, 2013: 13). 
Hal ini tidak sejalan dengan wacana Islamisasi keilmuan, ilmuisasi Islam, integrasi keilmuan, interkoneksi keilmuan hingga pendidikan terpadu ala Jaringan Sekolah Islam Terpadu (JSIT) yang hangat di bicarakan dalam mimbar akademik di Indonesia. Dua sistem pendidikan ini (dikotomi dan non dikotomi) nyatanya menghasilkan konflik tajam yang berlarut-larut dan sukar untuk di damaikan (Zaenal Mustakim, 2013:177). Akhirnya sikap dikotomi justru akan melahirkan masalah baru, yaitu masalah moralitas berupa nilai-nilai keagamaan yang hilang pada tataran masyarakat. Jika ini hilang, maka hancurlah tatanan sosial kemasyarakatan. Untuk apa ilmu pengetahuan maju namun moralitas digadaikan untuk membangun dunia. Maka praktik dikotomi keilmuan yang secara tidak langsung ditawarkan Barat, dirasa sangat cacat dan tidak relevan jika diterapkan dalam konteks Pendidikan Islam di Indonesia. Menurut Samrin, dapat nyata dari praktik dikotomi adalah krisis nilai pada peradaban manusia karena menganggap ilmu sebagai bebas nilai. Sedangkan bagi lembaga, praktik dikotomi akan menyebabkan kerapuhan pengetahuan agama dan atau sebaliknya (Samrin, 2013: 190).

Ciri khas lain dari Pendidikan Barat adalah antroposentrisme. Antroposentrisme ialah suatu paradigma dalam memotret kehidupan yang menempatkan posisi manusia sebagai sistem pusat atas seluruh sistem alam semesta ini. Paradigma ini berisi pemikiran bahwa seluruh aktivitas kebijakan yang dilakukan dan diambil oleh manusia mengenai lingkungan hidup maka harus despond dengan nilai-nilai yang berdasarkan manusia. Jadi, antroposentrisme menginginkan pusat pemikirannya atas semua hal di semesta ini adalah manusia. Menurut antroposentrisme alam harus tunduk dan diarahkan memenuhi seluruh kepentingan manusia. Paradigma moral lingkungan antroposentrisme disebut-sebut juga sebagai sebuah human centered ethic, karena memosisikan peran moral lingkungan hidup yang terpusat pada manusia. Maka jangan heran jika fokus perhatian terhadap pandangan ini terletak pada kesejahteraan dan kebahagiaan manusia di alam semesta. Menurutnya alam dilihat sebagai objek, alat atau sarana bagi pemenuhan kebutuhan dan kepentingan manusia (Mahbub Setiawan, 2013: 14). Pendidikan berbasis antroposentrisme dianggap sebagai akar masalah yang tercipta akibat interaksi manusia dengan lingkungan. Filsafat Antroposentrisme menghilangkan rasa hormat manusia kepada lingkungan sehingga memunculkan sikap ketamakan dan kesewenang-wenangan (Junaidi Abdillah, 2014: 67). Masalahmasalah tersebut lahir karena manusia menganggap dirinya spesies paling pusat dan paling penting di dunia ini.

\section{Jalan tengah}

Jika kita lihat paradigma pendidikan di barat, sebagaimana kajian diatas. Maka penulis menyimpulkan bahwa paradigma pendidikan Barat saat ini berorientasi kepada sistem kebenaran yang bertumpu kepada akal. Kemajuan yang diperoleh bangsa Barat saat ini harus kita akui akibat dari peranan akal namun menjurus kepada praktik sekulerisasi dan akhirnya terjebak dalam paham antroposentrisme. Lebih jelas akan diuraikan sebagai berikut:

GAMBAR 1. PARADIGMA PENDIDIKAN BARAT

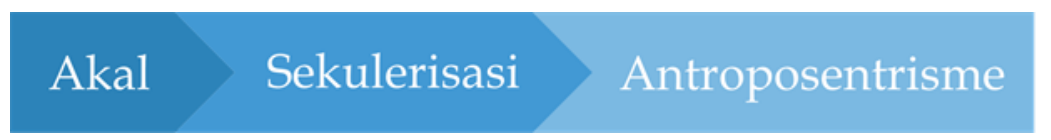

Dalam gambar 1, sangat jelas peranan akal dalam merespon berbagai seluruh sendi-sendiri kehidupan di Barat. Akal dijadikan sebagai sumber kebenaran yang bersinggungan dengan pengalaman empiris. Sehingga sesuatu dikatakan benar jika kebenaran tersebut masuk akal dan dapat dibuktikan secara jelas oleh indera manusia. Jika tidak, maka dianggap sebagai ketidak absahan sebuah kebenaran. Sehingga wajar, jika praktik terhadap pendewaan akal secara total akan menyebabkan praktik sekulerisasi, dan inilah wajah Pendidikan Barat saat ini. Agama sebagai menyemarakkan peradaban, bukan sebagai bukti autentik dan keabsahan dalam uji coba ilmu pengetahuan.

Fatal nya, eksistensi Tuhan dan wahyu-wahyu kemudian dinafikan, sekalipun penulis tidak dalam rangka menuduh secara frontal dan general, namun fakta-fakta tersebut sepertinya sulit untuk ditepis bangsa Barat. Bisa penulis katakan, majunya bangsa Barat saat ini justru akibat meninggalkan Agama. Sekalipun sudah ada berbagai usaha-usaha rekonstruksi paradigma pendidikan di Barat oleh para filosuf dan praktisi pendidikan. Namun, Akibat paradigma ini nampak jelas telah muncul sebuah paham yang mengakibatkan cara pandangan terhadap dunia juga ikut berubah, yaitu antroposentrisme. Suatu paham yang menjadikan manusia sebagai raja, sekaligus pusat dan paling penting dalam alam semesta.

Dari problem-problem Paradigma Pendidikan di Barat sebagaimana yang disebutkan diatas, penulis memandang paradigma Pendidikan Islam khususnya di Indonesia harus dikembalikan kepada sumber normatif berbagi ketuhanan yaitu firman-firman Tuhan, dalam hal ini disebut Wahyu. Lebih jelas akan diuraikan sebagai berikut: 


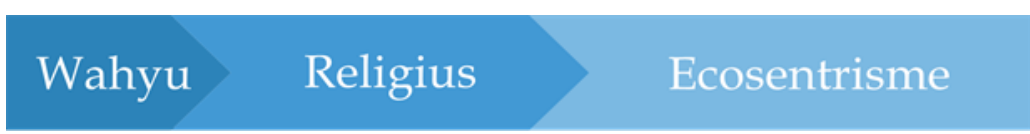

Hipotesis penulis, paradigma pendidikan Islam di Indonesia tampaknya sedikit banyak berkiblat kepada sistem pendidikan Barat. Standar-standar modernisasi dan kemajuan berdasarkan indikatorindikator yang disimpulkan dengan Pendidikan di Barat. Hal ini tentu akan bertentangan, jika proses adopsi membabi buta tanpa memilih dan memilah dalam tataran prinsip. Paradigma Pendidikan di Barat dan Islam jelas memiliki Value yang berbeda. Jika Barat menjadikan akal sebagai alat primer sebuah pengetahuan, maka Islam harus menjadikan wahyu sebagai alat sekaligus sumber Utama, seperti yang di jelaskan pada gambar 2. Lalu dimana fungsi akal dalam konteks Paradigma Pendidikan Islam? Jelas, akal berfungsi untuk membantu membuka tabir-tabir baik yang tersurat maupun yang tersirat dari pesan-pesan firman Tuhan.

Jika wahyu dijadikan landasan utama maka akan merespons sikap religius. Fakta-fakta ilmiah yang ditemukan dalam kitab Suci semakin memperkuat basis Iman umat Islam karena wahyu adalah keniscayaan dan tidak terbantahkan. Hasil dari sikap religius akan muncul paham yang disebut ekosentrisme (Sutoyo, 2013: 202). Sebuah paham yang muncul karena merespons kegagalan antroposentrisme yang tidak melibatkan peranan wahyu dalam Paradigma Pendidikan. Ekosentrisme adalah jalan tengah bagi Paradigma Pendidikan Islam, yaitu sebuah paham yang tidak menempatkan sebuah hierarki melainkan sebuah satu kesatuan ciptaan Tuhan yang saling membutuhkan atau simbiosis mutualisme. Jika Pendidikan Islam memiliki kesadaran ekosentris maka fungsi khalifah yang diwahyukan dalam al-Qur'an pasti dapat memakmurkan Dunia dengan baik dan benar, hasilnya tidak merusak sebagaimana klaim kebenaran yang dipegang oleh antroposentrisme yang berpotensi besar merusakan tatanan sosial dan alam semesta.

\section{KESIMPULAN}

Paradigma Pendidikan Barat berorientasi kepada pembuktian kebenaran dan keheranan dengan akal dan manusia sebagai pusat kebenaran sejati. Kritik tajam yang di sorot penulis terletak pada praktik sekulerisasi dan antroposentrisme akibat penggunaan rasionalitas secara total dan membabi buta. Hal ini tentu berseberangan dengan paradigma pendidikan Islam yang memiliki corak religius. Sekalipun demikian, paradigma pendidikan Islam sampai saat ini ternyata masih dalam tahap on going proses yaitu mencari formula dan jalan lain dalam menyusul perkembangan ilmu pengetahuan dan teknologi di Barat namun tetap tidak meninggalkan core value Pendidikan Islam. Peneliti menemukan jalan tengah bagi Paradigma Pendidikan Islam yaitu menjadikan wahyu sebagai sumber keabsahan yang autentik. Akibat dari keyakinan terhadap otentitas wahyu, maka muncul sikap religius yang bermuara kepada paham ekosentrisme. Ekosentrisme muncul karena merespons kegagalan antroposentrisme yang tidak melibatkan peranan wahyu dalam Paradigma Pendidikan. Ekosentrisme adalah jalan tengah bagi Paradigma Pendidikan Islam, yaitu sebuah paham yang tidak menempatkan sebuah hierarki melainkan sebuah satu kesatuan ciptaan Tuhan yang saling membutuhkan atau simbiosis mutualisme.

\section{REFERENSI}

Abdillah, Junaidi. Dekonstruksi tafsir Antroposentrisme: Telaah Ayat-ayat Berwawasan Lingkungan. Jurnal Kalam: Vol 8 No 1, 2014.

Ahida, Ridha. Sekulerisasi: Refleksi terhadap Konsep Ketuhanan. Jurnal Tajdid: Vol 25, No. 1, 2018

Arif, Syamsuddin. Orientalis dan Diabolisme Pemikiran. Jakarta: Gema Insani, 2008.

Asmuni, Ahmad. Kontribusi Islam Terhadapa Peradaban Barat. Jurnal Tamaddun: Vol. 5, No. 1, 2017.

Asy’ari, Hasyim. Renaissance Eropa dan Transmisi Keilmuan Islam ke Eropa. JUSPI: Jurnal Sejarah Peradaban Islam Vol. 2 No. 1, 2018.

Bekker, Anton. Metode-Metode Filsafat. Jakarta: Galia Indonesia, 1984

Bertens, K.. Ringkasan Sejarah Filsafat. Yogyakarta: Kanisius, 1986.

Fata, Ahmad Khoirul, dkk. Sekulerisme dan Tantangan Pemikiran Islam Kontemporer. Jurnal Madania, Vol. 20 No 2, 2016.

Jamaluddin. Sekulerisme: Ajaran dan Pengaruhnya Dalam Dunia Pendidikan. Jurnal Mudarrisuna: Vol 3 No 2,2013

Karim, Abdul. Sejarah Perkembangan Ilmu Pengetahuan. Jurnal Fikrah: Vol. 2 No. 1, 2014. 
Maiwan, Mohammad. Kosmologi Sejarah Dalam Filsafat Sejarah: Aliran, Teori dan Perkembangan. Jurnal Literasi: Vol. 3 No. 2, 2013.

Mustakim, Zaenal. Mengawinkan Keilmuan: Upaya Mengakhiri Dikotomi dan Mengintegrasikan Keilmuan dalam Pendidika Islam. Forum Tarbiyah: Vol. 11 No. 2, 2013

Samrin. Dikotomi Ilmu dan Dualisme Pendidikan. Jurnal Al-Ta'dib: Vol. 6 No. 1, 2013

Setiawan, Mahbub. Kritik Terhadap epistemologi Barat Modern "Perspektif Islamic Wordlview. UMS: Naskah Publikasi, 2013.

Subagyo, Joko. Metode Penelitian dan Praktek. Jakarta: Rhineka Cipta, 1991.

Suhelmi, Ahmad. Pemikiran Politik Barat. Jakarta: Gramedia Pustaka Utama, 2007.

Surajiyo. Filsafat Ilmu dan Perkembangannya Di Indonesia: Suatu Pengantar. Jakarta: Bumi Aksara, 2007.

Suryabrata, Sumadi. Metodelogi Penelitian. Jakarta: PT Raja Grafindo Persada, 2005.

Sutoyo. Paradigma Perlindungan Lingkungan Hidu. ADIL: Jurnal Hukum. Vol. 4 No. 1, 2013.

Suyanta, Sri. Transformasi Intelektual Islam Ke Barat, Jurnal Ilmiah Islam Futura: Vol. 10 No. 2, 2011.

Zarkasyi, Hamid Fahmi. Akar Kebudayaan Bara. Jurnal Kalimah: Vol. 2 No. 2, 2013. 